\title{
Determinants of User Awareness of New Information Systems - Electronic Tax Filing Perspective
}

\begin{abstract}
Information systems literature has been stuffed with much relating to the determinants of user acceptance, adoption and diffusion through applications of variety of theories such as Theory of Reasoned Action (TRA), Theory of Planned Behavior (TPB), Innovation Diffusion Theory (IDT), Model of PC Utilization (MPCU), Technology Acceptance Model (TAM1\&2) and Unified Theory of Acceptance and Use of Technology (UTAUT). The argument here is that such determinants also have their antecedents. For instance, awareness has been used as a determinant to either user intention or behavior towards acceptance, adoption or diffusion but little has been done in examining the determinants of awareness itself. This paper estimates the determinants (gender, age, education, internet experience, size and manual filing experience) of user awareness of new information systems from the perspective of electronic tax filing in Nigeria. Data was collected from the potential users in seven states in Northwestern Nigeria which was analyzed though Ordinary Least Squares regression analysis. It was found that gender, education, internet experience and manual tax filing experience are the significant determinants to user awareness of new information systems while age and size was found to be insignificant. The study contributes to the literature through focusing on an area neglected by previous researchers. It also contributes to the practice as the outcome of the study will be beneficial to policymakers in devising means for enhancing awareness of new information systems prior to actual adoption.
\end{abstract}

Abdulsalam Mas'ud
Index Terms: age, gender, educational qualification, experience, user awareness of information system.

\section{INTRODUCTION}

Information systems literature has been stuffed with much relating to determinants of user acceptance, adoption and diffusion of technology through application of variety of theories including but not limited to the Theory of Reasoned Action (TRA), Theory of Planned Behavior (TPB), Innovation Diffusion Theory (IDT), Model of PC Utilization (MPCU), Technology Acceptance Model (TAM1\&2) and Unified Theory of Acceptance and Use of Technology (UTAUT). It is argued here that such determinants may have their antecedents which left unexamined by researchers. For instance, awareness has been used as a determinant to either user intention or behavior towards acceptance, adoption or diffusion but little has been done in examining the determinants of awareness itself. Similarly, in TRA [1] and TPB [2] attitude has been one of the major variables influencing behavioral intention and behavior itself. Thus, it could be logical to argue that for an individual to be asked about his or her attitude towards the use a particular service, product or technology such individuals should be aware of such service, product or technology. Similarly, in TAM 1 [3] and TAM 2 [4] perceived ease of use or perceived usefulness of new information system have been determinants of user acceptance, however, for users to express their perceptions relating to ease of use and usefulness of a new information system they need to at least know little about it. This could equally be assumed in UTAUT [5] for effort expectancy and performance expectancy where a user can narrates such expectancies when asked only if he or she is aware of the system.

While these insights revealed the relevance of awareness in the acceptance and use of new information systems, the study on its antecedents has not much been documented in the literature. However, few researchers made effort in this regard such as a study that focused factors influencing awareness of electronic - based market information services for farming business in Malawi [6], and another study that focused on the determinants of awareness of ICT-based Market Information Services among smallholder farmers in Kenya [7]. Similarly, another scholar studied the determinants of green IT awareness among top-100 mid-size firms in Kenya using firm-level data [8]. These evidences clearly indicated that effort in understanding the factors influencing awareness is an issue in developing African countries; possibly due to different developmental trends in education and information technology usage with the rest if the world. Moreover, in all the available empirical evidences availed in the extant literature none is related to e-filing system, hence, the need to understand the determinants of awareness of e-filing system in developing country and specifically Nigeria.

There is justification for focusing this study towards this end. In Nigeria, while e-filing has been introduced since 2013 by federal government through Federal Inland Revenue Service (FIRS) via Integrated Tax Management System (ITAS), states government have been called to digitalized their tax collection systems by the President of Chartered Institute of Taxation of Nigeria (CITN) [9]. However, most of the taxpayers to states apart from employed individuals are micro-entrepreneurs who have low literacy and awareness of technological issues. Hence, studying the factors influencing their awareness of e-filing as a digitalized system of tax collection will have important policy implications to states government in Nigeria. The 
objective of this paper is to examine the determinants of efiling awareness among micro-entrepreneurs in Nigeria. Towards this end, the paper is divided into five parts with this as an introduction, followed by review of literature in the second section and methodology in the third. Result and findings are contained in the fourth part while the last part reports the conclusion and policy implication.

\section{LITERATURE REVIEW}

\section{A. E-filing Awareness}

In Nigeria e-filing has been introduced since 2013 at federal level through Federal Inland Revenue Service which is the authority responsible of tax collection among taxpayers that pay tax to federal government [24]. The system was introduced through the implementation of Integrated Tax Management System (ITAS) which was designed to store information of taxpayers so as to facilitate information sharing among relevant tax authorities as well as other stakeholders such as the Central Bank of Nigeria, Nigeria Customs Service, Corporate Affairs Commission, and National Bureau of Statistics amongst others [25]. The major aim of ITAS apart from data storage and integration is facilitating e-filing adoption so as to reduce interaction between taxpayers and tax authority [25]. Following this development at federal level, the President of Chartered Institute of Taxation of Nigeria (CITN) called the attention of states towards the use of technology for tax collections [9]. While this call can create urge for state to adopt e-filing within their tax system, however, they need to be mindful on the nature of the taxpayers within their jurisdiction. Most of their taxpayers are micro-entrepreneurs, who operate at the grassroots and may lack the desired awareness of the system to enable wider acceptance. This indicates the need to study the determinants of e-filing awareness among microentrepreneurs who are within the jurisdiction of SIRS/SBIR.

Awareness has been defined as a term which associates with sentience, perception, feeling and cognition on things, positions or programs which could be of various degrees [26]. Awareness was also considered as knowing the existence of particular issue in the society or understanding the nature of operation of a specific concept at a right time based on information or experience [27]. In the context of efiling system, it can be described as perceptions regarding the existence, concept and operating modalities of e-filing and how it differs from manual filing. Northwestern Nigeria which is the context of this study has been characterized with low literacy rate. All states in region covering Jigawa, Kaduna, Kano, Katsina, Kebbi, Sokoto, and Zamfara have literacy rate standing at $24.2 \%, 29.3 \%, 48.9 \%, 21.7 \%$, $23.5 \%, 30.1 \%$ and $33.9 \%$ respectively, which is far below the national average of 56.9\% [28]. Hence awareness will be an important variable in the implementation of e-filing in the region. It can be argued that low literacy can lead to low awareness which eventually can negatively affect the efiling acceptance, hence, the need for understanding the drivers of awareness of e-filing system.

Although there is available studies in the extant literature which examine the determinant of e-filing awareness are lacking, however earlier work such as TRA [1], TPB [2] TAM 1 [3] and TAM 2 [4] and UTAUT [5] highlights that the possibility of awareness to be one of the determinants of intention, acceptance, and adoption of information systems. However, such earlier studies do not highlight the antecedents of awareness, thus, left for future work. Extant literature has reported the determinants of awareness from other perspectives and jurisdictions such as gender [10], age [11], education [11, 12], and experience [13]. Other possible determinants such as size and manual tax filing experience were considered in alignment to the context of the study. Size was considered as the study focused on microenterprises which are of various sizes based on number of employees that ranged from one to nine. Similarly, manual filing experience was considered based on expectation that those taxpayers that have experience in filing their tax return manually would be possible to have awareness of the e-filing system through their interactions with the staff of tax authorities. Hence, the possible influence of these determinants on e-filing awareness will be hypothesized in the following sub-headings.

\section{B. Gender and E-filing Awareness}

The role of gender has long been recognized in the information system literature [5]. It was considered to have indirect influence on the acceptance and use of information systems. Evidence from the literature has shown that gender is an important determinant of information system awareness, for instance in the teacher education [10], ICT based market information system, though not significant [7] and electronic-based market information system for farmers [6] even though not statistically significant. While these evidences are apparent, evidence has not been availed by the extant literature on the effect of gender on information system awareness from the perspective of e-filing. Hence, the need to explore whether gender will be significant determinants of awareness in the context of e-filing among micro-entrepreneurs. Hence, the following hypothesis is proposed.

H1: Gender will have significant influence of e-filing awareness, with males having more awareness of e-filing among micro-entrepreneurs in Northwestern Nigeria.

\section{Age and E-filing Awareness}

Age is also recognized for long in information system literature especially within the domain of UTAUT [5]. It was considered to have indirect effect between information system acceptance and its determinants. Evidence also revealed the influence of age on environmental awareness [11] and women awareness of health services [12]. However, such empirical evidence are lacking in relation to the role of age on e-filing awareness especially among micro-entrepreneurs. In line with this gap identified in relation to lacking evidence on the role of age on information system awareness generally and e-filing in particular, the following hypothesis is postulated.

$\mathrm{H} 2$ : Age will have significant influence of e-filing awareness, with younger taxpayers having more awareness of e-filing among micro-entrepreneurs in Northwestern 
Nigeria.

\section{Educational Qualification and E-filing Awareness}

Educational qualification has been important individual specific variables in the study of many parts of human endeavors including information systems. Educational qualification was examined as one of the major determinants of information system security among librarian which was found to be slightly correlated [14]. Likewise, it was equally identified as key factor influencing environmental awareness [11] as well as women awareness of clinical services [12]. However, such evidence on the influence of educational qualification in relation to e-filing awareness has not been documented in the extant literature. To bridge this gap, the following hypothesis is postulated for validation among micro-entrepreneurs who will be the potential users of the e-filing system across SIRS/SBIR in Nigeria.

H3: Educational qualification will have significant influence of e-filing awareness, with those having higher educational qualification to be more aware of e-filing among micro-entrepreneurs in Northwestern Nigeria.

\section{E. Experience and E-filing Awareness}

Similar to age and gender, experience has also been identified for long as important variable in information system literature especially within the domain of UTAUT [5]. It was proposed and validated to have indirect influence between technology acceptance and usage and their determinants. In other context such as medicine, clinical experience was found to have influence on dental ethical awareness among students [13]. However, evidence is not available within the context of information system on the role of experience as a predictor or determinant of awareness. More appealing is that such has not been documented in the literature in relation to e-filing. Consequently, this study proposed that experience in using other internet related devises and system will have effect on e-filing awareness. Hence, the following hypothesis is postulated for empirical validation.

$\mathrm{H} 4$ : Experience in using other internet related system will have significant influence of e-filing awareness, with those having higher experience to be more aware of e-filing among micro-entrepreneurs in Northwestern Nigeria.

\section{F. $\quad$ Size and E-filing Awareness}

Size here refers to the number of employees working within a microenterprise. Microenterprises are those having one to nine employees based on definition given by Small and Medium Enterprises Development Agency of Nigeria [15]. It is considered as possible determinants of e-filing acceptance based on contextual justification. The argument here is that micro-entrepreneurs having large size of enterprises based on number of employees may have high information seeking behaviors compared with those having lower number of employees because they may be bond to comply with certain laws and regulations due to their large scale production or service provision. Equally, they may also experience more pressure regarding compliance with taxes for their employees. Following this argument the following hypothesis is postulated.
H5: Size of microenterprises will have significant influence of e-filing awareness, with those microentrepreneurs having larger number of employees to be more aware of e-filing among micro-entrepreneurs in Northwestern Nigeria.

\section{G. Manual Tax Filing Experience and E-filing} Awareness

Similar to size, the integration of manual tax filing experience among the determinants of e-filing awareness is contextually justified. It is integrated based on argument that those micro-entrepreneurs that have been filing their tax return manually could have more awareness of e-filing compared to those that either do not file tax return at all or file through an agent. The fact is that those that have experience in manual tax filing may likely be aware of the system through frequent interactions with staff of tax authorities on the conceptual and operational modalities of e-filing. Hence, following this argument, the following hypothesis is proposed.

H6: Experience in using manual tax filing will have significant influence of e-filing awareness, with those micro-entrepreneurs that have frequent interaction with tax authority staff through manual filing to be more aware of efiling among micro-entrepreneurs in Northwestern Nigeria.

Validation of these hypotheses will require careful selection of research methodology and regression model. Thus, to achieve this end the methodology followed and the regression model designed to achieve the purpose are presented in the following section.

\section{METHODOLOGY}

\section{A. Population and Sample}

The population of the study is 7,500, 000 microenterprises in Northwestern Nigeria based on SMEDAN report [15]. The states includes; Kano, Kaduna, Katsina, Jigawa, Zamfara, Sokoto, and Kebbi. Convenience sampling technique was employed to arrive at the sample size, based on literature that suggested that any population above 1,000,000 will have an approximate sample of 384 subjects [16]. However, the final usable responses were 380 which amounted to $98.9 \%$ response rate and considered highly sufficient for statistical analysis [17]. The sample across the seven states in depicted in Table 1.

Table 1: Population and Sample

\begin{tabular}{|c|l|c|c|}
\hline No. & State & $\begin{array}{c}\text { No. of Micro Enterprises } \\
\text { with }<10 \text { employees }\end{array}$ & Sample \\
\hline 1 & Kano & $1,700,000$ & 87 \\
\hline 2 & Kaduna & $1,600,000$ & 82 \\
\hline 3 & Katsina & $1,250,000$ & 64 \\
\hline 4 & Jigawa & 850,000 & 43 \\
\hline 5 & Zamfara & 700,000 & 36 \\
\hline 6 & Sokoto & 700,000 & 36 \\
\hline 7 & Kebbi & 700,000 & 36 \\
\hline Total & & $7,500,000$ & 384 \\
\hline
\end{tabular}

The numbers are based on approximations from Fig. 40 of SMEDAN (2013) Report. 


\section{B. Instrumentation}

Survey instrument was designed through which data was collected from the sample. Section one of the instrument contains demographic data of the respondents including; gender (male and female), age (below 30; 31 to 40 and 41 and above), qualification (no formal education; SSCE/GCE; ND/NCE; HND/BSC; and MBA/M.SC.), nature of enterprises (wholesale and retail; manufacturing; agriculture; accommodation and food; transportation and storage; construction; art, entertainment and recreation; information and communication; and others), number of employees (one; two; three; four; five; six; seven; eight; and nine), experience in using internet (none; 1-5 years; 6-10 years; and above 10 years), method of filing tax return (selffiling; through agent/intermediary; and not filing at all). Sections two contained scale items measuring awareness of e-filing. Five questions were utilized in measuring awareness of e-filing based on the questions adapted from [18]. These measure is based on five Likert Scale of $1=$ Strongly Disagree, $2=$ Disagree, $3=$ Neutral, $4=$ Agree and 5=Strongly Agree).

\section{Analytical Procedures}

The data collected from the sample undergone number of preliminary analyses to ensure that it satisfy the minimum requirements for the regression analysis. First, it was subjected to descriptive analysis so as to understand the nature of dispersion of the variables of the study and whether they are within the range of categories and scale use in the analyses. Second, normality of the data was also tested to ensure normal distribution using the relevant cutoff values. Thirdly, it was also subjected to correlation and linearity assessments. Having undergone these analyses, the regression analysis was conducted using Statistical Package for Social Sciences (SPSS) software V. 22.0.

\section{Models Specification}

The Ordinary Least Squares regression model of the study is expressed as follows. It has been derived in line with objective and hypotheses of the study.

AWN $i=\beta 0+\beta 1$ GEN $i+\beta 2$ AGE $i+\beta 3$ EDU $i+\beta 4$ EXP $\mathrm{i}+\beta 5$ SIZE $\mathrm{i}+\beta 6 \mathrm{TFE} \mathrm{i}+$ \&̇i.............................

Where:

$\mathrm{AWN}=$ Awareness

$\beta 0=$ Beta value of the constant

$\beta 1-\beta 4=$ Beta values of Gender, Age, Qualification, Internet Experience, Size and Manual Filing

$\mathrm{i}=$ Cross-sectional observations

$\dot{\varepsilon} \mathrm{i}=$ Error term

\section{RESULTS AND FINDINGS}

\section{A. Demographic Characteristics of the Respondents}

Analysis of the usable responses showed that $84 \%$ of the respondents were male while the remaining $16 \%$ were female, while $44 \%$ of the Micro-entrepreneurs surveyed were below 30 years, $40 \%$ aged 31 to 40 years, while the remaining $16 \%$ aged from 41 years and above. The respondents report diverse educational qualification with those having no any formal education standing $15 \%$, those holding SSCE/GCE certificates as 36\%, ND/NCE 27\%, followed by the holders of HND/BSC $20 \%$ and lastly the holders of MBA/MSC 2\%. Having covered wide-range of enterprises, the data showed that wholesale and retail subsector account for $35 \%$ of the sample, manufacturing $11 \%$, Food and accommodation 10\%, construction 9\%, transportation $7 \%$, agriculture $4 \%$, art, entertainment and recreation $4 \%$, information and communication $3 \%$ the remaining $17 \%$. For the size of micro-enterprises measured using number of employees, the data showed that enterprises with two to three employees have the highest coverage of $19 \%$ each. This is followed by those having four employees with $17 \%$, then enterprises having only the owner as employee representing $15 \%$, those having five employees $10 \%$, those having with seven and nine employees $6 \%$ each those with six employees are 5\% and the rest having eight employees represents $3 \%$ of the sample. The data further showed that only $24 \%$ of the respondents have no experience in using internet devises. Those having one to five years of experience in using internet devises covers $34 \%$, those with six to ten years $28 \%$ and those with more than ten years of using internet devises constitute $14 \%$. Regarding filing of tax returns, $28 \%$ are not filing their tax return, $25 \%$ are filing but through an agent/intermediary, while the rest of $47 \%$ are filing themselves.

\section{B. Descriptive Statistics of the Variables}

Descriptive analysis of the study's variable was performed to ascertain whether they are within the range of categories and scale used in the analyses as well as to understand the nature of their dispersions. The descriptive analysis of the seven variables including one dependent and six independent variables is reported. Four descriptive statistics covering minimum, maximum, mean and standard deviations are reported as shown in Table 2.

Table 2: Descriptive Statistics

\begin{tabular}{|c|c|c|c|c|c|}
\hline Variables & $\mathrm{N}$ & Min & Max & Mean & Std. Dev \\
\hline Awareness & 380 & 1 & 5 & 2.98 & .847 \\
\hline Gender & 380 & 1 & 2 & 1.85 & .360 \\
\hline Age & 380 & 1 & 3 & 1.71 & .719 \\
\hline Qualification & 380 & 1 & 5 & 2.57 & 1.02 \\
\hline Size & 380 & 1 & 9 & 3.78 & 2.26 \\
\hline Internet Exp & 380 & 1 & 4 & 2.33 & .995 \\
\hline $\begin{array}{c}\text { Manual Tax } \\
\text { Filing }\end{array}$ & 380 & 1 & 3 & 1.78 & .845 \\
\hline
\end{tabular}

From the descriptive analyses presented in Table 2 it is evident that 380 and usable responses were used for the analysis and none of the variables has score outside it measures. For example, awareness of was measured using 5Likert scale ranging from 1 to 5 which reflect the minimum and maximum values reported in Table 2. Gender was categorically measured as 1 and for male and female respectively while aged was categorized into 3 groups of 1 to 3 , which also reflect the minimum and maximum values reported. 
Educational qualification was ordered into five groups of 1 to 5 while size was measured using number of employees which ranged from 1 to 9 which equally reflect minimum and maximum values reported. Lastly, internet experience was categorized into four groups of 1 to 4 while tax filing experience was categorized three groups of 1 to 3 which also reflected the minimum and maximum values reported in Table 2. The responses of each of these variables are relatively dispersed based on the mean values and standard deviations reported.

\section{Normality}

Normality of data for variables is an important postulation of multivariate regression analysis [19]. The use of graphical approach to detect the non-normality of the error terms using histogram was suggested [20] so also the application skewness and kurtosis highlighting the problem of nonnormality through highly skewed and kurtotic data was also recommended [21]. In this study both approach were employed.

Table 3: Statistical Test of Normality

\begin{tabular}{|c|c|c|c|c|}
\hline \multirow{2}{*}{ Variables } & \multicolumn{2}{|c|}{ Skewness } & \multicolumn{2}{c|}{ Kurtosis } \\
\cline { 2 - 5 } & Statistic & SE & Statistic & SE \\
\hline Awareness & -.116 & .125 & -.280 & .250 \\
\hline Gender & -1.939 & .125 & 1.71 & .250 \\
\hline Age & .489 & .125 & -.951 & .250 \\
\hline Qualification & .170 & .125 & -.833 & .250 \\
\hline Size & .820 & .125 & -.131 & .250 \\
\hline Internet Exp. & .197 & .125 & -1.014 & .250 \\
\hline Manual Filing & .432 & .125 & -1.467 & .250 \\
\hline
\end{tabular}

From Table 3, the statistical test of normality using skewness and kurtosis indicated that the error terms are normally distributed. In reaching this conclusion the suggestions of [22] and [23] were followed which revealed that values should be less than 2 and 7 for Skewness and Kurtosis respectively. In addition, the analysis of normality using graphical approach reported in Fig.1 revealed same evidence, showing that normality is not a problem in this study as the histogram depicts bell sharp as required.

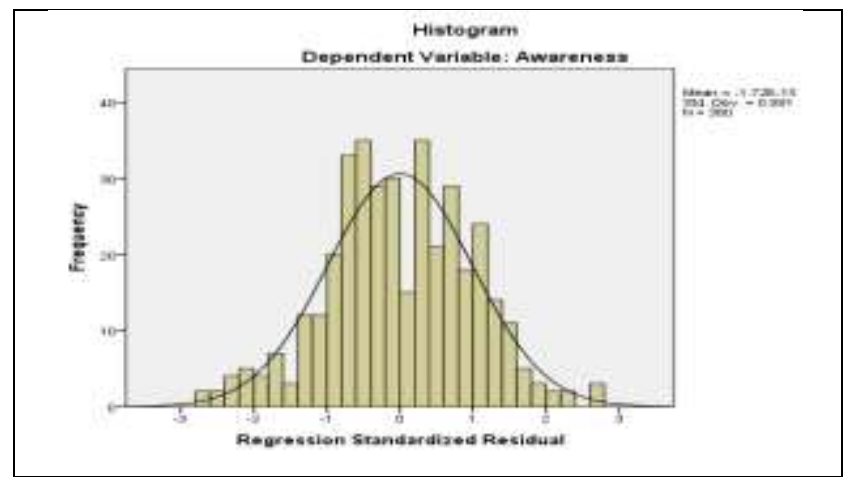

Fig. 1. Histogram for normality test

\section{Co-Linearity}

Co-linearity or multi-colinearity is another important postulation of multivariate regression analysis [19]. Existence of multi-colinearity indicates that the variables affected are performing same function within the research model, thereby revealing the redundancy of one of such variables. The use of Variance Inflation Factor (VIF) and Tolerance in evaluating co-linearity was suggested [21]. The result is reported in Table 4.

Table 4: Co-Linearity of the independent variables

\begin{tabular}{|c|c|c|}
\hline \multirow{2}{*}{ Variables } & \multicolumn{2}{|c|}{ Collinearity Statistics } \\
\cline { 2 - 3 } & Tolerance & VIF \\
\hline Gender & .974 & 1.027 \\
\hline Age & .975 & 1.026 \\
\hline Education & .781 & 1.281 \\
\hline Size & .961 & 1.040 \\
\hline Internet Experience & .781 & 1.281 \\
\hline Manual Filing & .962 & 1.040 \\
\hline
\end{tabular}

For the purpose of detecting the existence of co-linearity, Hair et al (2013) suggested that VIF above 5 and tolerance less than .20 is an indication of co-linearity. Following the result reported in Table 4, it can be concluded that colinearity is not an issue among the study's variables.

\section{E. Correlation}

In addition to the co-linearity, the level of correlation among all the variables was evaluated using Pearson's Correlation Matrix as reported in Table 5. It has been agreed that correlation above 0.90 indicate a potential problem high correlation will results in variable redundancy [19]. Based on the results reported in Table 5, it can be concluded that none of the variables are highly correlated to portray redundancy.

Table 5: Pearson Correlation Matrix

\begin{tabular}{|c||c|c|c|c|c|c|c|}
\hline Variables & 1 & 2 & 3 & 4 & 5 & 6 & 7 \\
\hline Awareness & 1 & & & & & & \\
\hline Gender & $-.14 * *$ & 1 & & & & & \\
\hline Age & .01 & .08 & 1 & & & & \\
\hline Education & $.15 * *$ & .02 & .05 & 1 & & & \\
\hline Size & .03 & $.09 *$ & .05 & $.09 *$ & 1 & & \\
\hline Internet Exp. & $.11 *$ & $.10 *$ & .06 & $.43 * *$ & $.14 *$ & 1 & \\
\hline Manual Filing & .04 & .01 & .05 & $-.17 * *$ & $.10 *$ & .03 & 1 \\
\hline
\end{tabular}

\section{F. $\quad$ Ordinary Least Squares Regression Analysis}

Following the satisfactory fulfillments of the preconditions of OLS regression analysis, the OLS result is reported for testing the hypotheses of the study. It can be recalled that all the independent variables; gender, age, educational qualification, size, internet experience and tax filing experience was projected to have significant influence on e-filing awareness among the sampled respondents. The result is reported in Table 6. 
Table 6: OLS Regression Results for Hypothesis Testing

\begin{tabular}{|c|c|c|c|c|c|}
\hline \multirow[b]{2}{*}{ Hypotheses } & \multicolumn{2}{|c|}{\begin{tabular}{|c|} 
Unstandardize \\
$\mathrm{d}$ \\
Coefficients
\end{tabular}} & \multirow[b]{2}{*}{$\mathrm{T}$} & \multirow[b]{2}{*}{ Sig. } & \multirow[t]{2}{*}{ Decisions } \\
\hline & $\mathrm{B}$ & SE & & & \\
\hline Gender & -.345 & .120 & 2.867 & 002 & Supported \\
\hline Age & .005 & .060 & .080 & .936 & Not Supported \\
\hline Qualification & .099 & .047 & 2.084 & .019 & Supported \\
\hline Size & .009 & .019 & .462 & .645 & Not Supported \\
\hline Internet Exp. & .066 & .049 & 1.358 & .088 & Supported \\
\hline Manual Filing & .067 & .052 & 1.300 & .097 & Supported \\
\hline
\end{tabular}

Hypothesis one projected that gender will have significant influence on e-filing awareness with male microentrepreneurs having high awareness compared to females, the results supports this postulations $(\beta=-0.345, \mathrm{t}=2.867$, $\mathrm{p}=.002)$. It revealed that gender is a significant determinant of e-filing awareness with women micro-entrepreneurs having less awareness compared to men. Hypothesis two postulates that age will have significant influence on e-filing awareness such that younger people will people will be more aware of the e-filing system. However, the result revealed contrary finding, it revealed that elders have more awareness of e-filing, though not significant $(\beta=0.005$, $\mathrm{t}=0.080, \mathrm{p}=.936)$. This indicates that within the context of this study age is not a significant determinant of e-filing awareness. Hypothesis three proposed that educational qualification will have significant influence on e-filing awareness with those having high qualification depicting high level of awareness, the results supports that this postulation $(\beta=0.099, t=2.084, p=.019)$. The result implied that educational qualification is a significant determinant of e-filing awareness such that highly educated microentrepreneurs depicts high level of awareness compared to lowly educated ones.

Hypothesis four projected that size will have significant influence on e-filing awareness with micro-entrepreneurs having larger number of employees to depict high awareness. The result from the analysis does not support this postulation $(\beta=0.009, \mathrm{t}=.462, \mathrm{p}=.645)$. Though microentrepreneurs with larger number of employees depict more awareness but such is not statistically significant. Thus, it shows that size is not significant determinant of e-filing awareness among micro-entrepreneurs in Northwestern Nigeria. Hypothesis five postulates that experience in using internet will have significant influence on e-filing awareness with micro-entrepreneurs that have higher years experience in using other internet related systems to have more awareness compared to those that have lower or no experience at all. The result supports this postulation $(\beta=$ $0.066, \mathrm{t}=1.358, \mathrm{p}=.088)$. The result confirmed that experience in using other internet related system is a significant determinant of e-filing awareness among microentrepreneurs in Northwestern Nigeria. Lastly, hypothesis six projected that experience in manual tax filing system will have significant influence on e-filing awareness, the result support this postulation $(\beta=0.067, \mathrm{t}=1.300, \mathrm{p}=.097)$. The result supports that manual filing experience is a significant determinant of e-filing awareness.

G. Statistical Power of the Model
The model of the study was evaluated using F-statistics which was found to be significant at less than one percent $(\mathrm{f}=2.807, \mathrm{p}=.007)$. This indicates that the determinants composed in the model fit together in explaining microentrepreneurs awareness of e-filing system. Moreover, the R-squared is 0.050 which implied that the variables explained only $5 \%$ of the changes in awareness of e-filing. This highlights the need to study other important variables not included in the model.

\section{CONCLUSION AND IMPLICATIONS}

This paper estimates the determinants of user awareness of new information systems from the perspective of electronic tax filing in Nigeria. It was built on the argument that while information technology acceptance, adoption and diffusion theories examine several determinants of user acceptance and use of information systems including awareness, literature is limited in exploring the antecedents of such determinants to enable wider and in-depth understanding of such theories.

The determinants examined here include; gender, age, education, internet experience, size and manual tax filing experience. Micro-entrepreneurs in northwestern Nigeria were used as samples. Ordinary Least Squares regression analysis was used in analyzing the data. It was found that gender, education and experience in using other internet related systems as well as manual tax filing experience are the significant determinants to user awareness of new information systems while age and size were found to be insignificant.

The study could have theoretical and policy implications. The study contributes to the literature through focusing to an area neglected by previous researchers; as such it theoretically provides wider understanding of information systems theories that highlight the role of awareness in acceptance and adoption of new information systems. It also contributes to the practice as the outcome of the study will be beneficial to policymakers in devising means for enhancing awareness of new information systems prior to actual adoption. Specifically, it shows that more awareness campaigns that will support the acceptance and use of efiling should concentrate on women compared to men. Age should not be a focus of e-filing awareness campaigns by States Inland Revenue Service/ States Board of Internal Revenue in northwestern Nigeria. Micro-entrepreneurs with less education qualification will require more awareness campaigns to ensure wider acceptance of e-filing. However, size of a microenterprise own by micro-entrepreneurs should not be a point of concerns by authorities while devising efiling awareness campaign strategies. Differently, experience in using other internet related systems as well as experience in using manual tax filing should be issues of concern in enhancing e-filing awareness among the potential users. This indicates that people with less experience in each of these two cases will require more awareness campaigns for e-filing systems. The study calls for further research of additional determinants that can explain awareness of 
e-filing among micro-entrepreneurs giving the low level of $\mathrm{R}$-squared reported.

\section{ACKNOWLEDGMENT}

This research data was obtained through Project (GV/16006) supported by ICTD, IDS, University of Sussex UK under grant from Bill and Malinda Gates Foundation.

\section{REFERENCES}

1. M. Fishbein, \& I. Ajzen, Belief, attitude, intention and behavior: An introduction to theory and research. Reading, MA: Addison-Wesley, 1995.

2. I. Ajzen, From intentions to actions: A theory of planned behavior. In J. Kuhl \& J. Beckmann (Eds.), Action York: Springer-Verlag, 1985.

3. F.D. Davis (1989). Perceived usefulness, perceived ease of use, and user acceptance of information technology. MIS quarterly, 319-340.

4. V. Venkatesh, \& F.D. Davis (2000). A theoretical extension of the technology acceptance model: Four longitudinal field studies. Management science, 46(2), 186-204.

5. V. Venkatesh, M.G. Morris, G.B. Davis, \& F.D. Davis (2003). User acceptance of information technology: Toward a unified view. MIS quarterly, 425-478.

6. S.P. Katengeza, J.J. Okello, \& E.R. Mensah (2011). Factors influencing of awareness and use of electronic based market information services for farming business in Malawi., Int. J. Eco. Res., 2(4), 43-58

7. J.J. Okello, O.K. Kirui, Z.M. Gitonga, G.W. Njiraini, \& J.M. Nzuma (2014). Determinants of awareness and use ICT-based market information services in developingcountry agriculture: The case of smallholder farmers in Kenya, Quarterly Journal of International Agriculture 53 (3), 263-282.

8. B.N. Karani. Determinants of green information technology awareness among top 100 mid-sized firms in Kenya. M.Sc. Dissertation, School of Computing and Informatics, University of Nairobi, Kenya, 2014.

9. C. Ikemefuna .(2018). Institute advocates technology based taxation system in Nigeria, The Nigerian Expression, 23 ${ }^{\text {rd }}$ May, 2018.

10. M.J. Philomina \& S. Amutha (2016). Information and communication technology awareness among teacher educators. International Journal of Information and Education Technology, 6(8), 603.

11. Z. Aminrad, S.Z.B.S. Zakaria, \& S.A. Hadi. (2011). Influence of age and level of education on environmental awareness and attitude: case study on Iranian students in Malaysian Universities. The Social Sciences, 6(1), 15-19.

12. S. Yaya, G. Bishwajit, M. Ekholuenetale, \& V. Shah (2017). Awareness and utilization of community clinic services among women in rural areas in Bangladesh: A cross-sectional study. PloS one, 12(10), e0187303.

13. K. Hertrampf, D. Groß, G. Karsten, \&H.J. Wenz, (2018). The influence of clinical experience on dental students' ethical awareness. European Journal of Dental Education.

14. S.K.W. Fakeh, M.N. Zulhemay, M.S. Shahibi, J. Ali, \& M.K. Zaini (2012). Information security awareness amongst academic librarians. Journal of Applied Sciences Research, 8(3), 1723-1735.

15. SMEDAN, SMEDAN and National Bureau of Statistics Collaborative Survey: Selective Findings (2013), Small and Medium Enterprises Development Agency of Nigeria, 2013, https://www.smedan.gov.ng/images/PDF/2013-MSMESurvey-Summary-Report.pdf Control: From Cognition to Behavior (pp. 11-39). New

16. R.V. Krejcie \& D.W. Morgan (1970). Determining sample size for research activities. Educational and Psychological Measurement, 30(3), 607-610.

17. U. Sekaran, Research methods for business, NY, 2003.

18. L.L. Keong, M.L. Khor, S.P. Low, \& Z.H. Wong (2012). Awareness of Islamic banking products and services among non-Muslims in Malaysia B.Sc. Dissertation, Department of Finance, Universiti Tunku Abdul Rahman, Malaysia.

19. B.G. Tabachnick, L. S. Fidell, and J.B. Ullman. Using multivariate statistics. Vol. 5. Boston, MA: Pearson, 2007.

20. J.F. Hair, W.C. Black, B.J. Babin, \& R.E. Anderson, Multivariate data analysis: Pearson Prentice Hall Upper Saddle River. NJ, 2010.

21. J.F. Hair, G.T.M. Hult, C. Ringle, \& M. Sarstedt. A primer on partial least squares structural equation modeling (PLS-SEM). Thousand Oaks, CA: Sage Publications, Incorporated, 2013.

22. P.J. Curran, S.G. West, \& J.F. Finch, (1996). The robustness of test statistics to normality and specification error in confirmatory factor analysis, Psychological Methods, 1(1)16.

23. S.G. West, J.F. Finch, \&P.J. Curran, (1995). Strictural equation models with nonnormal variables. Structural Equation Modelling: Concepts, Issues, and Applications, 56-75.

24. O. Stephen, I. Ayodotun, F.O. Iyoha, K.I. Charles, G. Daniel, (2017). Role of e-government in nigeria's tax system: strategy perspective to enhance compliance, The Social Sciences, 12(8), 1482-1486.

25. O. Arowolo \& F. Folarin (2014). Deloitte inside tax : Issue 35 - VAT exemption status: the controversy on basic food items tax/7fe9f2bdcbdf3410VgnVCM2000003356f70aRCRD. htm

26. R. Arp, (2007). Consciousness and awareness: Switchedon Rheostats: Response to de Quincey. Journal of Consciousness Studies, 14(3), 101-106.

27. A. Mas' ud, (2019). Acceptability of e-Filing of Taxes by Micro-Entrepreneurs in Northwestern Nigeria. ICTD Working Paper Series No. 96.

28. UNESCO, Nigerian Action Plan, High level International Round Table on Literacy "Reaching the 2015 Literacy Target: Delivering on the promise" UNESCO, Paris, 6-7 September 2012.

\section{AUTHORS PROFILE}

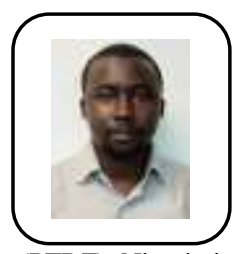

Dr Abdulsalam Mas'ud, CNA is a Full Time Visiting Senior Lecturer at Tunku Puteri Intan Safinaz School of Accountancy (TISSA), College of Business, Universiti Utara Malaysia. He obtained a B.Sc. (Accounting) from Bayero University, Kano Nigeria in 2005 with second class Upper. He won prestigious Petroleum Technology Development Fund (PTDF), Nigeria in 2009, which led his enrolment into M.Sc. (Oil and Gas Accounting) at Dundee Business School, University of Abertay - Dundee, UK and graduated in 2010 with Distinction. He completed his PhD at Othman Yeop Abdulllah Graduate School of Business, Universiti Utara Malaysia in 2016. His areas of specialization cover oil and gas accounting and taxation where he published articles in high indexed journals, such Energy Policy (Elsevier), International Journal of Energy Sector Management (Emerald), Biofuels (Tylor and Francis), International Journal of Energy Technology and Policy (Inderscience), International Journal of Enterprises Information Systems (IGI Global) among others. He has been Principal Investigator for number of international research grants IDS, University of Sussex and IRTI, Islamic Development Bank, Jedda. 